\title{
The Teachers' Pedagogic Competence in Teaching English through Online and Offline Setting
}

\author{
Nur Fadila Faidal \\ nurfadilahpaidal@gmail.com \\ Rafi'ah Nur \\ rafiahnur@yahoo.com \\ Suriani \\ Surianidjafar71@yahoo.com
}

Universitas Muhammadiyah Parepare

\begin{abstract}
Nowadays, a new trend in the teaching and learning process emerges along with the development of technology. This study aims at exploring the pedagogical competence of English teachers at SMPN 8 Satap Maiwa. It also aims at finding out the students' perceptions of their teachers' pedagogical competence. There were three kinds of instruments in this study. They were observation, interview, and a questionnaire. Based on the interviews, the results showed that the teachers enjoyed teaching in the classroom, and they were interested in conducting online instruction even sometimes found problems in doing the process. Based on the questionnaire, the researcher found students perceived their teachers as quite good instructors in the classroom. Finally, the researchers suggested to the teachers that they should always intend to improve their competence by applying some new methods to make students better understand the materials.
\end{abstract}

Keywords: Teachers, Pedagogic competence, online and offline media, Teaching English, Young Learners

\section{INTRODUCTION}

Some factors influence learning achievement. Those are students, teachers, learning materials, learning facilities, classroom management, and learning environment. These six aspects are giving their contributions and impacts to raise the expected learning objectives. However, the most important one is the teachers' skill in delivering the materials to gain an optimal contribution. Gurney (2007) claimed that some factors could provide a foundation for good teaching. Firstly, the teacher should possess in-depth knowledge, enthusiasm, and responsibility for learning. Secondly, the classroom activities should encourage learning. Thirdly, assessment activities encourage learning through experience. Fourthly, useful feedback establishes the learning processes in the classroom. Fifthly, effective interaction between the teacher and the students create an environment that respects, encourages, and stimulates learning through experience.

There are many factors, can make the learning process running well, but the important one is a teachers' job. Teachers should be able to influence their students into a better 
understanding. That is one of the reasons why teachers should competent in their field. Teachers need to have these competencies so that the learning process can achieve the learning objectives by the demands of the times. Rahman (2014) argued that in order to improve the performance of teachers, there is a need to improve the teacher's pedagogical competence and motivation. The teacher needs to improve pedagogical competence and motivation in managing the lesson, which has not achieved the goal of the lesson. Competence originated from oneself when one behaves according to the domain involved with achieving the desired result. Johnson (in Sanjaya 2008) said that "Competency as the rational performance which saves factorial meets the objective for the desired condition." Acting by expectations could make someone try to do the best to achieve the desired expectation. If a teacher wants to be a teacher with exemplariness, then the teacher would be well behaved.

There are four factors teachers should be mastered based on Standard Kompetensi Guru dan Peraturan Menteri Pendidikan Nasional no.16 on the year of 2007. Those are Pedagogic competence, Personal competence, Social competence, and professional competence. UUD or Peraturan Pemerintan has made regulations about The teachers' pedagogic. They are: 1) understanding the learners, 2) Mastering the theory of learning and principles of professional learning, 3) Developing the curriculum, 4) Developing learners' potential, 6) Communication with the learners, and 7) Implementing assessment and evaluation. Therefore, most teachers still cannot master those aspects; they do not have enough capability in teaching, especially in teaching the English Language.

Based on the assumption that early English instruction is a fundamental investment in this increasingly globalized world, (Garton, Copland, \& Burns, 2011) assumed that many countries had implemented the policy of introducing English into young learners' curricula. Therefore as an English teacher, we should also increase our global word by providing EYL students a better understanding of English, especially in our country, Indonesia.

From the problems and reasons stated previously, the researcher is interested in conducting research entitled "The Teachers' Pedagogic Competence in Teaching English through Online and Offline Setting" to know the improvements of some teachers in teaching English mainly to young learners.

\section{Pedagogic Competence}

Indonesian language teaching needs to get any useful approaches to be firmly grounded like second language learning. Madhavaram (2010) asserted that pedagogical competence was the ability of an individual to use a coordinated, synergistic combination of tangible resources and intangible resources to achieve efficiency and effectiveness in pedagogy. One of the vital factors and generally discussed the quality of education is the teacher. Hightower et al. (2011) claimed that a qualified teacher is a teacher who has a positive effect on student process of learning and development through a combination of content mastery, command of a broad set of pedagogic skills, and communications and interpersonal skills. It is commonly known when the learning objectives did not meet the targeted standard; the teacher will be the one to blame mostly. Indeed it is not fair because learning is a system or program influenced by many affecting factors mentioned earlier. Nevertheless, the perception toward the teacher's vital role in the success of learning is reasonable as in case there is an insufficient learning facility, we do still have hope if the teacher has standard competence to do so. Conversely, when the facility has been excellent, but the teacher's quality is low, it will not have a significant effect on obtaining learning objectives.

Meanwhile, based on the decree of Diknas no. 45 / U / 002 Competency means a set of intelligent action and full person responsibilities as a condition that the public should have 
in carrying out the task of professionalism. According to the Law number 14 the year 2005 about teacher and lecturer in section 1, subsection 10, mentioned: "Competence (capability) is a set of competence, knowledge, and behavior that the teacher or lecture must have to master to inspired the students in a learning process." Based on the previous explanation, the researcher defined that competence is the ability that the teacher has to influence the students into a better understanding of some perspectives given. In this case, the researcher needs to know whether English teachers are good enough to transfer their intelligent, ideas, and knowledge they have toward their students.

The concept of pedagogic competence also tends to be used with the meaning of the minimum professional standard, often specified by law, which should raise a person in fulfilling a particular role of the teaching profession (Gliga, 2002). The emphasis in understanding pedagogical competence should focus on the integrated features which outline the ability to solve educational problems. Therefore, the typical tasks should occur in situations of real pedagogical activities by applying knowledge, professional and life experience, values, and talents in a creative manner to obtain appropriate and effective results. Sampson and Fyrtos (2008) argue that competence has regarded the notion from the perspective of human resource management of vocational training and education, in the attempt to observe the importance of the interdependence between personal characteristics, proficiency level, and context. Richard in (2015) asserted that an excellent pedagogic competence is an aspect of teachers' knowledge and skills. It includes teachers' awareness, classroom management, interaction, teaching language skills such as reading, listening, speaking, writing, grammar and vocabulary, assessing language skills, and using the appropriate approaches, methodologies, techniques, and strategies. If teachers can master on those criteria, and they also can apply it in the classroom toward the students, it is mean that the teacher has an excellent pedagogic competence.

Another definition by Ryegård (2010) stated about an important thing that all teachers should understand is that what students' needs and want in the classroom. He disputes that learners do not like teachers who spend most of the time lecturing in the classroom. Lecturing time makes the students demotivated because they do not like being passive in class. Consequently, learners have limited input to the learning process. If it happens, the learning process will not run as well as the teacher expected. To be highly motivated teachers are needed to develop their competence.

The Association for the Professional Quality of Teachers, SBL (2004) mentioned that a pedagogically competent teacher suggests the students a safe learning and working environment, where they find their hold and a structure for social, emotional, and moral development. This competent teacher ascertains that the students:

1. Know that they belong, that they are welcome and appreciated

Treat respectfully each other and are challenged to take for one another

2. Take the initiatives and work autonomously

3. Learn to discover their affinities and ambitions, and from there make

4. The choice for study and career.

A study by Hamidi and Hatuti (2012) found that pedagogical affect performance and does not affect the professional competence of teacher performance, as well as personal competence, has a significant influence on the performance of teachers. Besides, Djamarah (2005) argued that teachers should possess the ability to manage the learning skills associated with creating and maintaining optimal conditions for the process of interaction. The indicators used to measure the ability to manage to learn include the teacher's knowledge of teaching materials; teaching methods and classroom management; create the conditions for active 
learning; develop instructional materials properly; improve the ability of students to understand the material by the purpose of learning.

\section{Concept of Online and Offline Setting in Learning Activity}

Today, the trend of online education becomes more intensive. Teachers realize that this trend becomes a demand of this era of industrial revolution 4.0. However, Singh et al., 2012) claimed that it remains a series of unanswered questions regarding the overall efficiency of these online classes versus the offline classes. The results of some researches comparing online versus face-to-face learning are various. The results ranged from online superiority to no difference to face-to-face superiority. Therefore, Singh et al. (2012) asserted that estimating the efficiency of students who take online courses relative to the efficiency of students who enrolled in offline courses expands upon the current thinking in the literature.

On the other hand, Biktimirov \& Klassen (2008) asserted that online courses enable the students to access the coursework, and potentially to high-quality teaching, that they may lack in their local school. However, they also worry that online learning may be more complicated than learning in the offline class. Hart et al. (2019) explained that the students who tended to be a procrastinated or who were unskilled in self-directed learning might suffer declines in performance if they lack a physically present teacher to direct their attention to the subject matter.

Besides, Berge \& Clark (2005) said that other students may be motivated but lack broadband or other technological resources that virtual courses rely on to enable smooth delivery. Even among students for whom technological resources do not pose a problem, some may have trouble in virtual courses if they lack the technical skills to make full use of the course content

Some scholars have found evidence that there was no difference between online and offline classes in terms of student performance based on their demographic characteristics (Huh et al.,2010). In evaluating the student performance based on student completion rates of materials, Olson (2002) also exhibited an indication that online versus offline delivery is a factor influencing a student's coursework completion.

Other researchers found that lower student performance in online classes. Detwiler (2008) stated that some even found higher learning in an online. In comparing the traditional and hybrid sections of Principles of Marketing, Priluck (2004) found no difference in performance, yet a significant difference in student satisfaction. Another consideration is given by McFarland and Hamilton (2005) that as studies predict student performance. The indications are the format of learning, i.e., offline or online, is not a sufficient treatment to influence the significant difference in a performance outcome. In two studies reviewed, student learning was presumed by using the student grades at the end of the course.

\section{Young Learners of English in Indonesia}

In this research, the researchers focus on teaching students at Junior High School, who still included as a young learner. There are many statements about the meaning of Young Learners here. Purwaningsih (2011) lists the Young Learners are learners in Elementary School aging 9-10 years old who are learning English as a foreign language. Based on that statement, young learners are students of primary school. They are students of English between the age of 7 and 15. Hoesein (2011) also assembled that young learners are the students of elementary 
school who are at grade four up to grade six. The students' ages range from ten to twelve years. They have studied English for about one to four years.

Young learners can learn more than one language. Therefore, the teacher should bring them into a better life with the English language. Ellis (2014) notes that the term young learner is vague and can lead to confusion. Legally, a young learner maybe anyone who is under the age of 18. In reality, however, using one term to cover such a diverse age range is unhelpful. Young learners are different from older children in many ways, especially when they learn something. Studies of young learners show how learning changes across development. Yuvaraj (2009) argues that in the early two years until late puberty, children possess critical periodll, which is closely related to language acquisition. Meanwhile, Brewster (1997 asserted that children's learning requires activities that support young learners with activities that move from the abstract to the concrete. The teachers should realize that young learners need more concrete activities than abstract ones.

Brumfit (1997) mentioned some characteristics of young learners. First, young learners only begin their schooling so that teachers have a significant opportunity to build their expectations of life in school. Second, they are potential, as a group for the children is near to their heterogeneous home cultures and newcomers to the conformity increasingly imposed across cultural grouping by the school. Third, they tend to become keen and enthusiastic learners. Fourth, learning can be closely linked to their expansion of ideas and concepts because it is adjacent to their initial experiences of formal schooling. Fifth, they need physical actions and activities as much as stimulations for their thinking and closer together.

The learners want their learning to be meaningful, meet their interests, and related to their everyday experiences (Dörnyei and Ushioda, 2001). Cameron (2001) also disputes that young learners are continually interacting with the environment around them and trying to cope with some problems that they possibly encounter in that environment. Within this growth, young learner students might find difficulties. Besides that, Harmer (2001) also states that young learners love to explore things that can trigger their imagination so that activities like arranging puzzle, drawing, doing games and doing physical movement will suit them best. However, the teacher should make sure that, along with those various activities, the learning process is taking place. Besides, to develop specific language skills, teachers need to ensure that learners have experiences in lessons that will build those skills. Classroom in this context, taking place as the world that gives learners opportunities to involve in some activities given by the teacher.

\section{METHOD}

The researcher applied qualitative research and quantitative research. Qualitative research is characterized by an inductive approach that focuses on interpreting their participant's perspectives. The researcher focuses on describing teachers' competence.

In finding the right data of teachers' pedagogic competence in teaching English at SMPN 8 Satap Maiwa, the researchers collected data through observations, interviews, and questionnaires.

The researcher conducted observations in every class when learning English takes place. Then, the researcher processed data by using statistics. The results of the process data were described by investigators using descriptive design. This research has two variables, namely teachers' pedagogic competence in teaching English to Young Learners and the students' perception of their teachers' competence. 
The research subjects are two English teachers at SMPN Satap 8 Maiwa and students there. This research studied the teacher because the researcher wants to find out directly how is the practice of pedagogical competence of teachers when teaching in the classroom so that the researcher can get the real data. Besides, the researcher hopes that the results of this research can be a reference for English teachers at the school to further enhance learning practices in primary class about teacher pedagogical competence.

\section{RESULTS AND DISCUSSION}

1. The Pedagogical Competence of the English Teachers

To explore the pedagogical competence of the English teachers at SMPN 8 Satap Maiwa, the researchers conducted interviews. The teachers were given questions to know their pedagogic competence. They were:

1. How did they apply many approaches, strategies, and methods creatively

2. Did they increase the syllabus and RPP by yourselves?

3. How did they use media through online and offline settings in teaching the students?

4. How did they evaluate the process and result of learning activity?

The creativeness of the teachers in applying approaches, methods, and strategies of language teaching

After interviewing the teachers, the researchers found some facts related to the teachers' creativity in applying the materials in the classroom. The creativity covers the application of appropriate approaches, methods, and strategies of language teaching in the classroom. The researcher found that both English teachers gave students appropriate materials based on student's proficiency. The transcripts of the interviews between the researchers and teachers are as follows.

\section{Teacher 1}

"I usually give students materials based on what they want, and I know that most students like to play a game on their age. Therefore, I apply such kind of games in giving the materials. I mention like words match game, observe and remembered a game, puzzle game, etc.... and I found that most student seems interested to join the learning activity, also I am as a teacher... should know what my students need in order to make them understand the materials well, that is why I apply many strategies.

\section{Teacher 2}

"I use blackboard rarely because I understand that most students feel bored when I am writing on the blackboard. That is why I only focus on how I can make my students understand the learning materials in fun way with applying many methods and strategies in the classroom. Also, most students cannot understand the materials well when I always teach them in the classroom. Therefore I want to make a change to that. So, sometimes, I bring them to go outside of the classroom and teach them.

Based on the teachers' answers above, the researchers inferred that both English teachers already applied good approaches, methods, or even strategies in teaching English in the classroom. ....... which meant that these English teachers have a good capability in making the students an interest in joining the learning process.

\section{Ways of designing syllabus and RPP}

In the second question of the interview, the researchers asked about whether both English teachers increase their syllabus and RPP or not. The researchers also want to know 
how they design their syllabus and RPP. Based on their answers, the researchers found that both teachers already design their syllabus and RPP themselves selves, and they match it with the school condition.

\section{Teacher 1}

"Based on what I see in the classroom. I try to make students can understand the materials with real objects. That's is why I give them materials based on what the things they can see, and they feel in this area in order to make them can understand the materials well, so I increase and follow this RPP myself'.

Teacher 2

"I ever teach my students material about "short notice," I told them to look at the picture of the thing that they have not seen before, a and..... So, I increase my RPP and write down the thing that my students have seen, and I try to make the students can describe a thing that they see in the classroom".

Based on the teachers' answers above, the researchers conclude that both English teachers really have a good way of designing their syllabus and RPP because they match it with the condition of the school itself.

\section{The application of online and offline media in teaching English}

In the third question given to both teachers, the researchers found that English teachers suddenly apply both online and offline settings in teaching English. The teachers said that most students could more improve their English learning after applying online settings in the school. Teacher 1

"I... sometimes apply the online setting and also sometimes apply the offline setting. It can improve my students' comprehension. Mention like when I want to improve my students speaking, I let them open such kind of application in their laptop or even their smartphone.... Like Youtube, right? They can improve their speaking by directly watch a short movie. And they can follow it. And... when I apply the offline setting, I just let them learn by many apply games in the classroom as usual'.

\section{Teacher 2}

"Yes, I usually apply online setting when I teach in the classroom. It also makes it easy to teach my students. I ever teach them through WhatsApp application. I told them to do their assignment by looking at the questions that I send to them through WhatsApp. And... I see them interesting to do their assignment with it."

Based on the teachers' answers above, the researchers infer that both English teachers applied both online and offline settings in teaching English. It means that both English teachers already applied such a good strategy in teaching English in that school.

\section{Ways of conducting assessment and evaluation}

On the last question, the researchers found some facts related to the teachers' ways of conducting assessment and evaluation. The researcher found that both English teachers gave students a score based on the capacity of their students include the students scored when the teachers gave them evaluation.

\section{Teacher 1}

"I give students an assessment and evaluation at the end of the study. The way I give them an assessment based on their comprehension. I do not only see from their capability in answering the question I gave, but I also see from their attitude and their attendance in the 
classroom. Kind of evaluation I gave them is also the materials that I have tough them, and I think that most of the students already understand the materials I give with the strategies that I have applied in the classroom. Moreover, the students who still do not have enough capability in answering the question, I try to improve their understanding by directly approve them and knowing their problem, so that I can give an appropriate solution toward them.

\section{Teacher 2}

"Kind of evaluation I give to the students is the materials that they can answer based on their capability. However, I still follow the curriculum. Even some students still cannot understand the materials well, but at least I can solve their problem by change my method that will make them easy to understand the materials."

According to the result of the interview, the researchers found the summarizing answered by the teachers. First question, the teachers use emotional approaches to know what the students' requirement and what made them lack in learning, the teacher used cooperative learning in teaching so that the teacher can be able to increase the students' knowledge. The second question, the teachers try to develop the syllabus because the teachers want to match with the school's condition. In the third question, the teachers suddenly apply both online and offline settings in teaching English, and it can improve the students' ability. The last, the teacher always gave an evaluation in every last minute of the meeting.

Based on the observation, the researchers put seven items on the observation list as follows:

1. Teachers' prime knowledge about students in the classroom

The researchers found that teachers already know and understand the characters of their students. They also know what their students want and what the students need. Therefore, the teachers can give them an excellent method of teaching, in order to make them the interest in the learning activity.

2. Teachers' respond to students when asking

The learning process can be categorized as a good activity if there is feedback between teachers and the students. Moreover, the researchers found that the teachers gave excellent responses to the students when they are asking a question, and it makes students can be easier in understanding the materials.

3. The use of curriculum and syllabus

The existence of a curriculum and syllabus helps the teachers to develop their lessons plan. Also, the teacher can design the forms of assessment easier for each intended indicator. Therefore, both English teachers use curriculum 2013, which is mean students are standing as a stakeholder for implementing the learning activity.

4. The use of media in teaching

As we know that the use of media has a big influence on learning activity. It can help teachers to improve the quality of students. The researchers also found that the media used by the teachers is available and appropriate with the students' condition. For example, like a laptop, smartphone, LCD projector, tape recorder, poster, comic, radio,

5. An application of online and offline setting in a learning activity

Online and offline settings in teaching English have their benefits toward the students and also the teachers. Online settings in teaching English can be categorized as a good way of improving the students' capability in learning English. Most of the students in era globalization are often apply online settings when they are teaching in the classroom. Also, in this school, both teachers apply online and offline settings when they teach the students. Example of the online setting is watching the video in YouTube, teaching the students via WhatsApp application, listening to the voice of English language from the internet, etc. When the teachers 
applied the offline setting, they applied many methods in teaching such as playing a game, and using media.

6. The teachers give an evaluation to students after teaching

Evaluation is useful to know the students' comprehension after giving the materials. It aims to know whether the students understand the materials given or not. It is also has been applied by these English teachers. They gave student evaluations to know their understanding. They give students score at the last of the meeting.

7. Teachers give students some tasks.

Assigning tasks in the classroom has benefits for the students, for example, involving the students in their learning, making course topics come to life, deepening students' knowledge, and developing particular skills. Moreover, both English teachers usually gave the students a task after giving the materials. It is mean that these English teachers already know how to evaluate their students well.

According to the Great Dictionary of Indonesia, teachers understood as a person who works in university teaching school, building a place of learning, colleges, high schools, and universities. Act number 14 of 2005, article 1, paragraph 1 states. Teachers are professional educators with the primary task of educating, teaching, guiding, directing, train, assess, and evaluate students in early childhood education, formal education, primary education, and secondary education.

Teachers are people who are very influential in the teaching-learning process. Therefore, teachers should bring their students to achieve the objectives. The teacher must be Teachers must be able to influence their students. Teachers must be visionary and authoritative. Corresponding to the Rule of Government NO. 19 In the year 2005 about the National Education Standard section 28, subsection 3 explained the definition of pedagogic and professional competence. The pedagogic competencies are the ability to manage the teachinglearning process includes the understanding of learners, lesson design of learning, evaluation of learning outcomes, and the development of learners to actualize their competence

\section{Students' Perception of Teachers' Pedagogic Competence}

Based on the questionnaire filled out by the students, the researchers found that the students perceive their teachers' pedagogic competence were good. It is proved to mean score of students' perception of their teachers' pedagogic competence. Most of the respondents choose Agree (A) category. It is proved by the average score of students' answer is 42, 76 in Agree category, 32, 40 in Strongly Agree category, 20,72 in Disagree category, and 4,11 in Strongly disagree category. It indicated that the students considered their English teachers have good pedagogic competence in teaching English. Sujanto in Dina (2009: 30) states that perception is a process that is preceded by sensing, which is a process of the physical receipt of stimulus by the individual using its receptor.

The data on teachers' pedagogic competence obtained through a questionnaire. Students' questionnaire of teachers' pedagogic competence has four alternatives. The researcher used the formula to know the questionnaire as follow: 


\begin{tabular}{|c|c|c|c|c|c|c|c|c|c|c|}
\hline \multirow{2}{*}{ Q uestionnaire } & \multicolumn{2}{|c|}{ SA } & \multicolumn{2}{|c|}{ A } & \multicolumn{2}{|c|}{ D } & \multicolumn{2}{|c|}{ SB } & \multicolumn{2}{|c|}{ TOTAL } \\
\hline & $\mathrm{f}$ & $\%$ & $\mathrm{f}$ & $\%$ & $\mathrm{f}$ & $\%$ & $\mathrm{f}$ & $\%$ & $\mathrm{f}$ & $\%$ \\
\hline $\begin{array}{l}\text { 1. The teachers gave approprite } \\
\text { materabs }\end{array}$ & 11 & 28.95 & 17 & 44.74 & 9 & 23.68 & 1 & 2.63 & 38 & $100,8 \varepsilon$ \\
\hline $\begin{array}{l}\text { 2. The Teachets helped students to } \\
\text { in prove the students' ab illy }\end{array}$ & $?$ & 18.42 & 22 & 57.89 & 7 & 18.42 & 2 & 5.26 & 38 & $100, \theta \mathrm{E}$ \\
\hline $\begin{array}{l}\text { 3. The Teachers used seme media in } \\
\text { teaching Englioh }\end{array}$ & $=$ & 21.85 & 4 & 10.53 & 26 & 63.16 & 2 & 5.26 & 38 & $100.8 \varepsilon$ \\
\hline $\begin{array}{l}\text { 4. The Teachers gave evaluation } \\
\text { through a simple test }\end{array}$ & $1 \theta$ & 26.32 & 17 & 44.74 & 9 & 23,68 & 2 & 5.26 & 38 & $100.0 \varepsilon$ \\
\hline $\begin{array}{l}\text { 5. The teachets used media such as } \\
\text { hpte } p / 0 m a r t p h e \text { in teaching Eng lioh }\end{array}$ & 10 & 26.32 & 21 & 38.26 & $s$ & 13.16 & 2 & 5.26 & 38 & $100.0 \varepsilon$ \\
\hline $\begin{array}{l}\text { 6. The teachers knew how to } \\
\text { determ he the barning strategy as the } \\
\text { otudents' characteriblic }\end{array}$ & s & 21.95 & 23 & 68.53 & 3 & 13.16 & 2 & 5.26 & 38 & $100,8 \varepsilon$ \\
\hline $\begin{array}{l}\text { 7. The teachers knew the use of online } \\
\text { setting as the teaching materiab }\end{array}$ & 23 & 60.53 & $1 \theta$ & 26.32 & 4 & 18.53 & 1 & 2.63 & 38 & $100, \theta \varepsilon$ \\
\hline $\begin{array}{l}\text { 8. the teachers artanged the bssen } \\
\text { plan as the ches sen barning otrategy }\end{array}$ & 8 & 21.85 & $1 \theta$ & 26.32 & 16 & 42.11 & 4 & 10.53 & 38 & $100, \theta \mathrm{E}$ \\
\hline $\begin{array}{l}\text { 9. The teachers can set a gead learning } \\
\text { atm osphere }\end{array}$ & 6 & 15.79 & $2 \theta$ & $\$ 2.63$ & 18 & 26.32 & 2 & 5.26 & 3. & $100, \theta \varepsilon$ \\
\hline $\begin{array}{l}\text { 18. The teachero dit the barning } \\
\text { activity using media based on hiternet } \\
\text { in giving the materia b }\end{array}$ & 18 & 26.32 & $2 \theta$ & 32.63 & 6 & 18.79 & 2 & 5.26 & 38 & $100, \theta \varepsilon$ \\
\hline $\begin{array}{l}\text { 11. The teachers did an cualuation } \\
\text { pracess and the resur of teaching } \\
\text { Eng lith centins us with seme metheds }\end{array}$ & 10 & 26,32 & $2 \theta$ & 52,63 & 6 & 15.79 & 2 & 5,26 & 38 & $1 \ominus \odot, \theta \varepsilon$ \\
\hline $\begin{array}{l}\text { 12. The teachers uoes Internet basod } \\
\text { an Iine when toaching Englibh }\end{array}$ & 10 & 47.37 & 18 & 47.37 & 1 & 2.63 & 1 & 2.63 & 38 & $100 . \theta \varepsilon$ \\
\hline $\begin{array}{l}\text { 13. The teachers analyzed the precess } \\
\text { of teaching and the resull to determ ine } \\
\text { te kvel of students }\end{array}$ & 15 & 39.47 & 12 & $31.5 \mathrm{~s}$ & 11 & 23. 95 & $\theta$ & 8.00 & 30 & $100, \theta \varepsilon$ \\
\hline $\begin{array}{l}\text { 14. The teachets used online medis in } \\
\text { teaching in order to in prove the qualily } \\
\text { of earning pregram }\end{array}$ & 32 & 84.21 & 6 & 15.79 & $\theta$ & 8.00 & $\theta$ & 8.80 & 38 & $100, \theta \mathrm{E}$ \\
\hline $\begin{array}{l}\text { 15. The teachers facifitated the } \\
\text { students to in prove their academ ic } \\
\text { potential }\end{array}$ & 12 & 31.58 & 13 & 34.21 & 11 & 28.95 & 2 & S. 26 & 38 & $100, \theta €$ \\
\hline $\begin{array}{l}\text { 16. The teachers facilitated students } \\
\text { with the online and effline medih to } \\
\text { inpreve the studento' nen academ is } \\
\text { petential }\end{array}$ & 9 & 23.69 & 27 & 71.95 & 2 & 5.26 & $\theta$ & ๑.อย & 39 & $100.0 \varepsilon$ \\
\hline & 197 & 818.4211 & 260 & 684.2105 & 126 & 331.8789 & 25 & 65.78947 & & \\
\hline & 12.3125 & 32.48132 & 16.25 & 42.76316 & 7.875 & 28.72368 & 1.5625 & 4.111842 & & \\
\hline
\end{tabular}

Standard:

Highest score:

Lowest score

Number of students

Scale

Number of items 
A good pedagogical competence means that teachers know the students' characteristics, they can develop a curriculum and creating a good atmosphere in the classroom, they have feedback from students, and also they give an evaluation at the end of learning material. Based on the table, the researchers know that both English teachers at SMPN 8 Satap Maiwa already have a good pedagogic competence.

The researchers found, based on questionnaire sheet, that most answers have done by the students is in the agree category. It indicated that their English teachers already have a good capability in teaching English. In other words, the students said that English teachers have good pedagogic competence. It meant that most students agreed that both English teachers in their school have a good capability in teaching the English language.

Based on the Likert Scale, the score of strongly disagree (608), disagree (1064), agree (1520), and strongly agree (2432). The score that the researchers found on the students' answer is on the agree category (1845) from the maximum score is 2432. It is proved that English teachers have good pedagogic competence in teaching English.

\section{Discussion}

According to the Great Dictionary of Indonesia, teachers understood as a person who works in university teaching school, building a place of learning, colleges, high schools, and universities. Act number 14 of 2005, article 1, paragraph 1 states. Teachers are professional educators with the primary task of educating, teaching, guiding, directing, train, assess, and evaluate students in early childhood education, formal education, primary education, and secondary education.

Teachers are people who are very influential in the teaching-learning process. Therefore, teachers should bring their students to the objectives to achieve. The teacher must be able to influence their students. Teachers must be visionary and authoritative. Corresponding to the Rule of Government NO. 19 In the year 2005 about the National Education Standard section 28, subsection 3 explained the definition of pedagogic and professional competence. The pedagogic competencies are the ability to manage the teachinglearning process includes the understanding of learners, lesson design of learning, evaluation of learning outcomes, and the development of learners to actualize their competence

Base on the definition of pedagogic competence, the researchers finally found the students" perception of teachers' Pedagogic Competence. According to Sujanto in Dina (2009), Perception is a process that is preceded by sensing, which is a process of tangible receipt of stimulus by the individual by means of its receptor. Then the stimulus was forwarded to the central nervous system, the brain, and there was a psychological process so that the individual is aware of what he saw, heard, and so forth.

Students in the general sense are that every person who receives the influence of a person or group of people who run education. Thus, the perception of students is the response or acceptance of the students is a direct response in interpreting what is captured through the senses by students. Based on the result of the research, the students' perceptions of the pedagogic ability of teachers of English shows that both English teachers are included as a good category on their pedagogical competence.

Based on the result of the interview, observation, and questionnaire, the teachers' pedagogic competence was included as a good category because, in the result of the interview, the researcher found that the teacher was always doing the every item question in the teaching and learning process. It is also proved by the students' questionnaires about their perspective of their English Teachers. 


\section{CONCLUSION}

From the discussion in the previous chapter, based on the interview asked toward the teachers and observation did by the researcher, she found that both English teachers can be concluded as functional categories in Teaching English at SMPN. 8 Satap Maiwa.

1. English teachers also categories as good in their pedagogical competence, because based on a questionnaire given to the students, most of them answer in to agree and strongly agree on category, which is means that English teachers have excellent pedagogic competence in teaching English at SMPN. 8 Satap Maiwa.

2. The students perceive their English teachers as competent instructors.

\section{Suggestion} as follows

Based on the finding and the conclusion, the researchers put some suggestion

1. On the conclusion above, the researchers proposes the following suggestions:

2. The students should pay attention to what the teacher explains to making the learning process running well. If they do not understand the material or teacher explanation, they should ask their teacher.

3. The teacher should give or prepare good material to make the students more interested in learning because the teaching material gives influence to the students' understanding. The teacher also has to know what students' difficulties in learning English is, and help to solve their problem.

4. Teachers can utilize the internet to teach students to make the learning process more enjoyable.

5. Teachers' pedagogic competence is very good at teaching English. It is a research method conducted by teachers who want to help students master the subject or material. The primary purpose of teacher pedagogic competence is to find out and to solve the students' problems in the class and improve their achievements. It is beneficial for educators and students. Therefore, the teachers are suggested to have pedagogic competence research if their students have problems in the teaching and learning process in the classroom.

\section{REFERENCESS}

Biktimirov, E.N. and Klassen, K.J. (2008).Relationship between use of online support materials and student performance in an introductory finance course. Journal of Education for Business, 83, Retrieved on June $15^{\text {th }} 2019$

Departemen Pendidikan dan Kebudayaan. (2014). Peraturan menteri pendidikan nasional nomor 22 tahun 2016 tentang standar proses pendidika ndasa rdan menengah. Jakarta: Depdikbud.

Departemen Pendidikan dan Kebudayaan. (2007). Peraturan menteri pendidikan nasionl nomor 16 tahun 2007 tentang standard kompetensi guru. Jakarta: Depdikbud 
Djamarah, SB 2005.Teachers and Learners in Educational Interaction Psychological A theoretical approach.Rineka Reserved. Jakarta.

Hart, C.M.D, Berger, D., Jacob, B., Loeb, s., Hill, M. (2019). Online Learning, Offline Outcomes: Online Course Taking and High School Student Performance. AERA Open. 5(1). $1-17 \quad$ retrieved from https://journals.sagepub.com/doi/pdf/10.1177/2332858419832852?download=true

Hamidi, M and Indrastuti, S., 2012. Influence Analysis of Competence, Educational Background on Performance PolikteknikBengkalis Lecturer of Leadership Perspective. Proceedings of the National Seminar on Industry and Technology. December 26, 2012.

Hightower, A. M., Delgado, R. C., Lloyd, S. C., Wittenstein, R., Sellers, K., \& Swanson, C. B. (2011). Improving student learning by supporting quality teaching.(Online) Retrieved on $\quad$ February 17th 2019 from http://www.edweek.org/media/eperc_qualityteaching_12.11.pdf.

Madhavaram, S., Laverie, D.A. (2010).Developing Pedagogical Competence: Issues and Implications for Marketing Education. Journal of Marketing Education, vol. XX, no X, pp. 2-10.

McFarland, D. and Hamilton, D. (2005-2006). Factors affecting student performance and satisfaction: Online versus traditional course delivery. Journal of Computer Information Systems, (Winter), 25-32.

Singh, S., Rylander, D. H., Mims, T.C. (2012). Efficiency of Online vs. Offline Learning: A Comparison of Inputs and Outcomes. International Journal of Business, Humanities and Technology. 2 (1). 93-98.

Sudjana, Nana. (2004). PenilaianHasil Proses BelajarMengajar. Bandung: Remaja Rosdakarya,2002.

Sugiyono, (2014).Research methods for applied linguistics. In: A. Davies and C. Elder, (Eds.), The Handbook of Applied Linguistics (pp. 49). Oxford, UK: Blackwell 